\title{
Elaboration of Simplest Folding Structures in 2-Dimensional Lattice with Delta-Hemolysin and Its Variants in HP Model
}

\author{
Shaomin Yan ${ }^{\circledR}$, Guang $W u$
}

State Key Laboratory of Non-food Biomass Enzyme Technology, National Engineering Research Center for Non-Food Biorefinery, Guangxi Key Laboratory of Biorefinery, Guangxi Academy of Sciences, Nanning, China

Correspondence to: Guang Wu, hongguanglishibahao@gxas.cn

Keywords: Folding Structure, Delta-Hemolysin, HP Model, Hydrophobicity Index, Lattice, Minimal Energy, Native State

Received: April 11, $2019 \quad$ Accepted: May 18, $2019 \quad$ Published: May 21, 2019

Copyright $\odot 2019$ by authors and Scientific Research Publishing Inc.

This work is licensed under the Creative Commons Attribution International License (CC BY 4.0).

http://creativecommons.org/licenses/by/4.0/

\section{(c) (i) Open Access}

\section{ABSTRACT}

Although the advanced 3-dimensional structure measurements provide more and more detailed structures in Protein Data Bank, the simplest 2-dimensional lattice model still looks meaningful because 2-dimensional structures play a complementary role with respect to 3-dimensional structures. In this study, the folding structures of delta-hemolysin and its six variants were studied at 2-dimensional lattice, and their amino acid contacts in folding structures were considered according to HP model with the aid of normalized amino acid hydrophobicity index. The results showed that: 1) either delta-hemolysin or each of its variants could find any of its folding structure in one eighth of 1,129,718,145,924 folding structures because of symmetry, which reduces the time required for folding, 2) the impact of $\mathrm{pH}$ on folding structures is varying and associated directly with the amino acid sequence itself, 3) the changes in folding structures of variants appeared different case by case, and 4) the assigning of hydrophobicity index to each amino acid was a way to distinguish folding structures at the same native state. This study can help to understand the structure of delta-hemolysin, and such an analysis can shed lights on NP-problem listed in millennium prize because the HP folding in lattice belongs to a sub-problem of NP-problem.

\section{INTRODUCTION}

With the advance of technologies in 3-dimensional structure measurements, more and more detailed structures are documented in Protein Data Bank [1,2]. Therefore, the protein folding models become paler compared with real structures, especially the 2-dimensional model whose results deem meaningless and doubtful. However, why do we need to study the Newton's physics after having had the Einstein's theory? Why 
should we not destroy all photo devices, which record 2-dimensional pictures while our world is 3-dimensional?

Actually, the simplest 2-dimensional lattice model looks more meaningful nowadays than before because: 1) 2-dimensional structures do not exist in reality and thus play a complementary role with respect to 3-dimensional structures; 2) the folding in 2-dimensional lattice tells the ways of how a protein folds since 3-dimensional data document only limited ways that a protein folds if any; 3 ) the ways that a protein folds provide a clue how a protein folds itself within a very tiny interval of time; 4) it is more efficient and effective to optimize computing algorithms in 2-dimensional lattice rather than in 3-dimensional lattice; 5) the computation of exhaustive folding structures would be a good measure of how the computing power advances; 6) models can tell us the future whereas data only record the past; and 7) our daily experience indicates that we are comfortable to have a family album rather than a collection of 3-dimensional statues of family members, i.e., 2-dimensional data are easier to store than 3-dimensional data.

At this moment, the hydrophobic-polar (HP) model would scornfully emerge in our mind because it folds a protein along 2-dimensional and 3-dimensional lattices [3, 4]. Nevertheless, the HP model is widely considered too simple compared with real-life case, because it just classifies amino acids as either hydrophobic $(\mathrm{H})$ or polar $(\mathrm{P})$, and converts an amino acid sequence into an HP sequence, and folds the HP sequence along lattices, and finally counts the number of $\mathrm{H}-\mathrm{H}$ contacts. However, at the native state of folding structure, the contact between any two amino acids can reach $400\left(20^{2}\right)$, i.e., AA contact, AR contact, VV contact, so the computation is huge if one wants to find a native state with certain amino acids contacts. From this viewpoint, studies of protein folding along 2-dimensional lattice should not be abandoned.

As a matter of fact, any amino acid sequence should fold in the same way in lattices no matter whether it is an HP sequence or amino acid sequence, a self-avoiding way, i.e., left, ahead, and right. Actually, the HP folding in lattice belongs to a sub-problem of NP-problem listed in millennium prize [5-7]. This means if humans want to solve the NP problem, we have to study the HP folding despite some view that this type of studies is out-of-fashion. The real truth is that we do not know much about folding structures in 2-dimensional lattice because of the lack of computing power.

Staphylococcus aureus is a Gram-positive bacterium that can be found in the upper respiratory tract and on the skin [8]. S. aureus can secrete hemolysins to cause cell death [9]. Hemolysins at least include $\alpha$-, $\beta$-, $\gamma$ - and $\delta$-hemolysins, and each plays a different role in damaging of cell membrane as determined by 3-dimensional structures [10-12]. However, their 2-dimensional structures have yet to be studied by HP model. Because the length of $\alpha$-, $\beta$-, and $\gamma$-hemolysins are composed of more than 300 amino acids, it is only practical to study $\delta$-hemolysin that is composed of 26 amino acids [13]. Although the $\delta$-hemolysin has been studied for nearly 50 years, its high potency against Legionella was reported recently [14, 15], and its anti-pathogenic activity may inhibit quorum sensing pathways [16]. The mechanism of antimicrobial and cytolytic peptides in model membranes suggested that the Gibbs energy of binding to the membrane is the primary determinant of peptide activity [17].

With the advance of computing power, it is possible to analyze all $\delta$-hemolysin's folding structures in 2 -dementional lattice because it is short and composed of 26 amino acids. Even so, the number of its possible folding structures in 2-dimensional lattice is astonishing, i.e., $4 \times 3^{n-2}=4 \times 3^{(26-2)}=$ $1,129,718,145,924$. However, a duo $2 \mathrm{GHz}$ CUP ThinkPad laptop can compute 200,000 folding structures per second, thus it needs 65 days $(1,129,718,145,924 / 200,000=5,648,591$ second $)$ to compute all the possible folding structures. Actually, each mutant also has the same number of folding structures. Therefore researchers concentrate themselves on developing optimal algorithms in order to minimize computations as many as possible $[5,18-23]$. This study will analyze all possible folding structures of $\delta$-hemolysin from $S$. aureus and its variants.

\section{MATERIALS AND METHODS}

\subsection{Data}

Amino acid sequences of $\delta$-hemolysin and its variants were obtained from the UniProt [24] with the accession number P0C1V1. Six natural variants were found in canine, including the variants at position 3 
$\mathrm{Q} \rightarrow \mathrm{A}$, positions 10-12 GDL $\rightarrow \mathrm{VEF}$, position $15 \mathrm{~W} \rightarrow \mathrm{L}$, positions 17-18 $\mathrm{ID} \rightarrow \mathrm{AE}$, position $21 \mathrm{~N} \rightarrow \mathrm{E}$ and position $24 \mathrm{~T} \rightarrow \mathrm{I}[25]$.

\subsection{Sequence in 2-Dimensional Lattice}

The HP model is simple because it classifies each amino acid either as hydrophobic $(\mathrm{H})$ or as polar (P) although there are several neutral amino acids. If those neutral amino acids are dealt properly, the HP model would work in real-life case, for which the normalized amino acid hydrophobicity index (Table 1), where only glycine is considered as a neutral amino acid [26].

Table 1. Normalized amino acid hydrophobicity index.

\begin{tabular}{|c|c|c|c|}
\hline \multicolumn{2}{|c|}{ At $\mathrm{pH} 2$} & \multicolumn{2}{|c|}{ At pH 7} \\
\hline \multicolumn{4}{|c|}{ Very Hydrophobic } \\
\hline $\mathrm{L}$ & 100 & $\mathrm{~F}$ & 100 \\
\hline $\mathrm{I}$ & 100 & I & 99 \\
\hline $\mathrm{F}$ & 92 & $\mathrm{~W}$ & 97 \\
\hline $\mathrm{W}$ & 84 & $\mathrm{~L}$ & 97 \\
\hline $\mathrm{V}$ & 79 & $\mathrm{~V}$ & 76 \\
\hline M & 74 & M & 74 \\
\hline \multicolumn{4}{|c|}{ Hydrophobic } \\
\hline $\mathrm{C}$ & 52 & $\mathrm{Y}$ & 63 \\
\hline $\mathrm{Y}$ & 49 & $\mathrm{C}$ & 49 \\
\hline $\mathrm{A}$ & 47 & $\mathrm{~A}$ & 41 \\
\hline \multicolumn{4}{|c|}{ Neutral } \\
\hline $\mathrm{T}$ & 13 & $\mathrm{~T}$ & 13 \\
\hline $\mathrm{E}$ & 8 & $\mathrm{H}$ & 8 \\
\hline G & 0 & G & 0 \\
\hline$S$ & -7 & S & -5 \\
\hline Q & -18 & Q & -10 \\
\hline $\mathrm{D}$ & -18 & & \\
\hline \multicolumn{4}{|c|}{ Hydrophilic } \\
\hline $\mathrm{R}$ & -26 & $\mathrm{R}$ & -14 \\
\hline $\mathrm{K}$ & -37 & K & -23 \\
\hline $\mathrm{N}$ & -41 & $\mathrm{~N}$ & -28 \\
\hline $\mathrm{H}$ & -42 & $\mathrm{E}$ & -31 \\
\hline \multirow[t]{2}{*}{$\mathrm{P}$} & -46 & $\mathrm{P}$ & $-46($ used $\mathrm{pH} 2)$ \\
\hline & & $\mathrm{D}$ & -55 \\
\hline
\end{tabular}


This leads an amino acid sequence to have four HP sequences with respect to: 1 ) whether glycine was as hydrophobic amino acid or as polar one, and 2) whether the amino acid sequence was at $\mathrm{pH} 2 \mathrm{or}$ at $\mathrm{pH}$ 7 . In this way the amino acids of $\delta$-hemolysin and its variants were converted, and there were $28 \mathrm{HP}$ sequences listed in Table 2.

Table 2. Conversion of amino acid sequences of $\delta$-hemolysin and its variants into HP sequences.

\begin{tabular}{|c|c|c|}
\hline$\delta$-hemolysin and its variants & Classification & Sequence \\
\hline \multirow[t]{5}{*}{ Original } & Amino acid & MAQDIISTIGDLVKWIIDTVNKFTKK \\
\hline & $\mathrm{G}=\mathrm{H}$ at $\mathrm{pH} 2$ & ННРРННРНННРННРНННРННРРННРР \\
\hline & $\mathrm{G}=\mathrm{P}$ at $\mathrm{pH} 2$ & ННРРННРННРРННРНННРННРРННРР \\
\hline & $\mathrm{G}=\mathrm{H}$ at $\mathrm{pH} 7$ & ННРРННРНННРННРНННРННРРННРР \\
\hline & $\mathrm{G}=\mathrm{P}$ at $\mathrm{pH} 7$ & ННРРННРННРРННРНННРННРРННРР \\
\hline \multirow[t]{5}{*}{ Variant position 3, Q $\rightarrow \mathrm{A}$} & Amino acid & MAADIISTIGDLVKWIIDTVNKFTKK \\
\hline & $\mathrm{G}=\mathrm{H}$ at $\mathrm{pH} 2$ & НННРННРНННРННРНННРННРРННРР \\
\hline & $\mathrm{G}=\mathrm{P}$ at $\mathrm{pH} 2$ & НННРННРННРРННРНННРННРРННРР \\
\hline & $\mathrm{G}=\mathrm{H}$ at $\mathrm{pH} 7$ & НННРННРНННРННРНННРННРРННРР \\
\hline & $\mathrm{G}=\mathrm{P}$ at $\mathrm{pH} 7$ & НННРННРННРРННРНННРННРРННРР \\
\hline \multirow[t]{5}{*}{ Variant positions $10-12$, GDL $\rightarrow$ VEF } & Amino acid & MAQDIISTIVEFVKWIIDTVNKFTKK \\
\hline & $\mathrm{G}=\mathrm{H}$ at $\mathrm{pH} 2$ & ННРРННРННННННРНННРННРРННРР \\
\hline & $\mathrm{G}=\mathrm{P}$ at $\mathrm{pH} 2$ & ННРРННРННННННРНННРННРРННРР \\
\hline & $\mathrm{G}=\mathrm{H}$ at $\mathrm{pH} 7$ & ННРРННРНННРННРНННРННРРННРР \\
\hline & $\mathrm{G}=\mathrm{P}$ at $\mathrm{pH} 7$ & ННРРННРНННРННРНННРННРРННРР \\
\hline \multirow[t]{5}{*}{ Variant position $15, \mathrm{~W} \rightarrow \mathrm{L}$} & Amino acid & MAQDIISTIGDLVKLIIDTVNKFTKK \\
\hline & $\mathrm{G}=\mathrm{H}$ at $\mathrm{pH} 2$ & ННРРННРНННРННРНННРННРРННРР \\
\hline & $\mathrm{G}=\mathrm{P}$ at $\mathrm{pH} 2$ & ННРРННРННРРННРНННРННРРННРР \\
\hline & $\mathrm{G}=\mathrm{H}$ at $\mathrm{pH} 7$ & ННРРННРНННРННРНННРННРРННРР \\
\hline & $\mathrm{G}=\mathrm{P}$ at $\mathrm{pH} 7$ & ННРРННРННРРННРНННРННРРННРР \\
\hline \multirow[t]{5}{*}{ Variant positions $17-18, \mathrm{ID} \rightarrow \mathrm{AE}$} & Amino acid & MAQDIISTIGDLVKWIAETVNKFTKK \\
\hline & $\mathrm{G}=\mathrm{H}$ at $\mathrm{pH} 2$ & ННРРННРНННРННРННННННРРННРР \\
\hline & $\mathrm{G}=\mathrm{P}$ at $\mathrm{pH} 2$ & ННРРННРННРРННРННННННРРННРР \\
\hline & $\mathrm{G}=\mathrm{H}$ at $\mathrm{pH} 7$ & ННРРННРНННРННРНННРННРРННРР \\
\hline & $\mathrm{G}=\mathrm{P}$ at $\mathrm{pH} 7$ & ННРРННРННРРННРНННРННРРННРР \\
\hline \multirow[t]{5}{*}{ Variant position $21, \mathrm{~N} \rightarrow \mathrm{E}$} & Amino acid & MAQDIISTIGDLVKWIIDTVEKFTKK \\
\hline & $\mathrm{G}=\mathrm{H}$ at $\mathrm{pH} 2$ & ННРРННРНННРННРНННРНННРННРР \\
\hline & $\mathrm{G}=\mathrm{P}$ at $\mathrm{pH} 2$ & ННРРННРННРРННРНННРНННРННРР \\
\hline & $\mathrm{G}=\mathrm{H}$ at $\mathrm{pH} 7$ & ННРРННРНННРННРНННРННРРННРР \\
\hline & $\mathrm{G}=\mathrm{P}$ at $\mathrm{pH} 7$ & ННРРННРННРРННРНННРННРРННРР \\
\hline \multirow[t]{5}{*}{ Variant position $24, \mathrm{~T} \rightarrow \mathrm{I}$} & Amino acid & MAQDIISTIGDLVKWIIDTVNKFIKK \\
\hline & $\mathrm{G}=\mathrm{H}$ at $\mathrm{pH} 2$ & ННРРННРНННРННРНННРННРРННРР \\
\hline & $\mathrm{G}=\mathrm{P}$ at $\mathrm{pH} 2$ & ННРРННРННРРННРНННРННРРННРР \\
\hline & $\mathrm{G}=\mathrm{H}$ at $\mathrm{pH} 7$ & ННРРННРНННРННРНННРННРРННРР \\
\hline & $\mathrm{G}=\mathrm{P}$ at $\mathrm{pH} 7$ & ННРРННРННРРННРНННРННРРННРР \\
\hline
\end{tabular}




\subsection{Folding Structures}

Each of $28 \mathrm{HP}$ sequences theoretically had 1,129,718,145,924 folding structures, which were determined by a Dawning 5000 supercomputer with 180.6 trillion floating-point operations per second.

\section{RESULTS AND DISCUSSION}

As have seen, the merit of HP model is to divide amino acids into hydrophobic $(\mathrm{H})$ or polar $(\mathrm{P})$, then it is easy to find out the native state of folding structure with maximal $\mathrm{H}-\mathrm{H}$ contacts, whereas it is quite laboring to find any amino acid contacts with respect to any combination of two amino acids. Of $1,129,718,145,924$ folding structures, we are only interested in the structures at native state defined by $\mathrm{H}-\mathrm{H}$ contacts.

Figure 1 shows several characteristics of eight folding structures of $\delta$-hemolysin. First, $\delta$-hemolysin begins to fold from position 1 to position 26 no matter whether HP sequence or amino acid sequence. Second, each non-sequential H-H contact constructs a unit of negative energy according to the definition in HP model while this definition could also be any other contact, which certainly results in different folding structures. Third, the symmetric characteristic holds for eight folding structures, i.e., 1) the folding structures on left-hand side are vertically symmetric to the folding structures on the right-hand side; 2) the folding structures between I and VI, between II and V, between III and VIII, between IV and VII are horizontally symmetric; and 3) the folding structures between I and V, between II and VI, between III and VII, and between IV and VIII are 180-degree rotating symmetric. If we carefully examine the eight folding structures in Figure 1, those structures are identical, but fold through eight different pathways in 2-dimensional lattice. This means that a protein needs far less time to fold itself than previous assumed [27]. Actually, such symmetric structures are chiral structures in terms of 3-dimensional structures, which lead to different recognition mechanisms in enzymatic functions. This really shows the complementary role of 2-dimensional structures to 3-dimensional structures because it can explain the chiral center in terms of folding of amino acids.

As we deal with glycine either as hydrophobic $(\mathrm{H})$ or polar $(\mathrm{P})$ according to the normalized amino acid hydrophobicity index (Table 1), Figure 2 presented this influence on the folding structure of $\delta$-hemolysin. As can be seen, the sole glycine at position 10 was subject to different considerations. When the glycine was classified as polar amino acid, the minimal energy changed to - 11 from -12 (bottom panels vs. middle panels in Figure 2). Another issue is whether $\mathrm{pH}$ levels could influence the folding structure. Actually, in this particular case, the influence of $\mathrm{pH}$ on the folding structure was not found because both folding structure and minimal energy were the same in the left and right panels of Figure 2. On the other hand, the $\mathrm{pH}$ influence could be seen by the summed values of normalized hydrophobicity index to the amino acids that constructed $\mathrm{H}-\mathrm{H}$ contacts (the values in parentheses).

Figures 3-8 showed the folding structures of variants of $\delta$-hemolysin, which highlighted various influence of mutated amino acid. For example, the same folding structure at native state could be found in Figure 4, Figure 6 and Figure 7 but not in Figure 3, Figure 5, and Figure 7. The minimal energy was changed in Figure 3, Figure 5, Figure 7 and Figure 8 due to different classification of the glycine, however, such a change was not found in Figure 4 and Figure 6, and particularly the mutation led the glycine to be absent in Figure 4. Also, the minimal energy was changed in Figure 4, Figure 6 and Figure 7 at different $\mathrm{pH}$, which also shows influence on misfolding $[28,29]$. Therefore, whether $\mathrm{pH}$ affects $\mathrm{H}-\mathrm{H}$ contacts should be determined case by case (Figures 2-8).

Moreover, structures in those figures suggested that a native state could have several different structures. Table 3 showed detailed analyses, where $\mathrm{pH} 2$ and pH 7 are the references to determine whether an amino acid is hydrophobic $(\mathrm{H})$ or polar $(\mathrm{P})$ in the normalized amino acid hydrophobicity index (Table 1), and $\mathrm{G}=\mathrm{H}$ as well as $\mathrm{G}=\mathrm{P}$ are whether glycine was considered as hydrophobic $(\mathrm{H})$ or polar $(\mathrm{P})$. In example of $\delta$-hemolysin (first entries, Table 3 ), the negative values (-12 and -11 ) were the minimal energy determined by the number of non-sequential $\mathrm{H}-\mathrm{H}$ contacts. As can be seen, a native state can have many folding structures, for example, 2160 and 7552 folding structures at $\mathrm{pH} 2$ with $\mathrm{G}=\mathrm{H}$ and $\mathrm{G}=\mathrm{P}$. As there 
Native state I

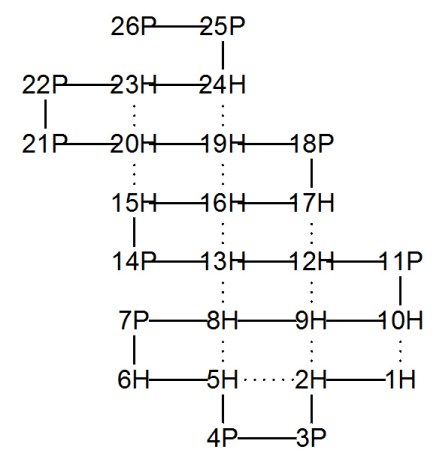

Native state III
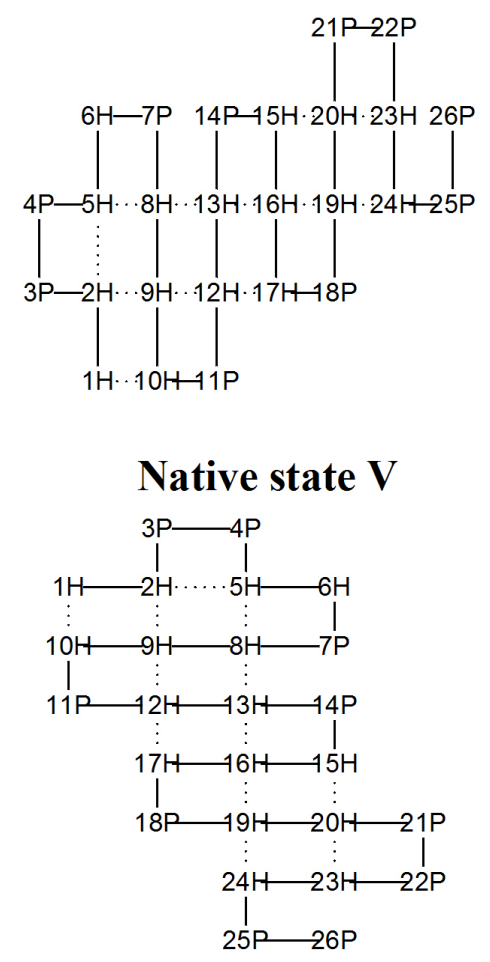

Native state VII

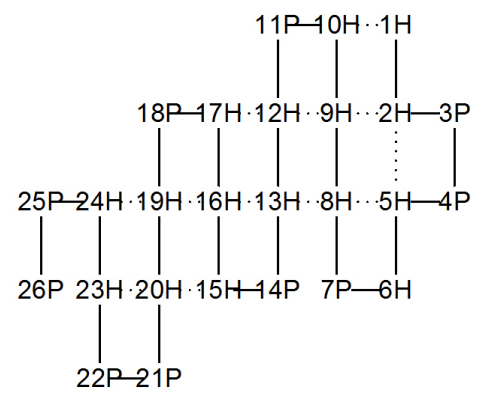

Native state II

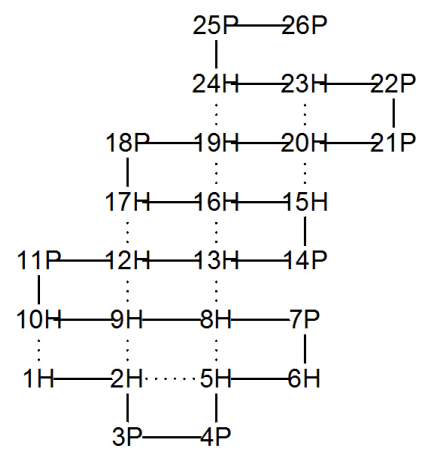

Native state IV

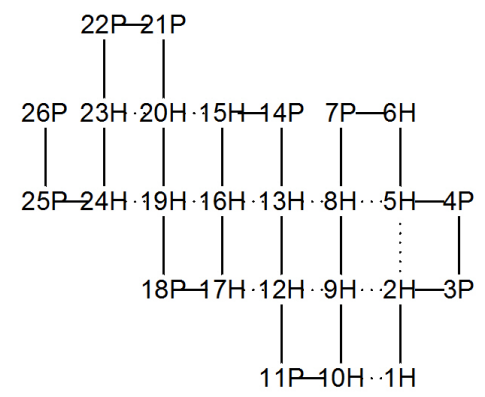

Native state VI



Native state VIII

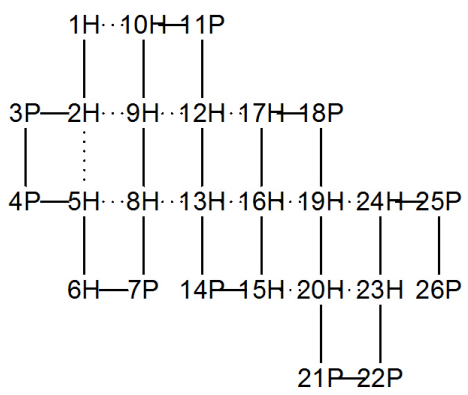

Figure 1. Folding structures of $\delta$-hemolysin under the condition of glycine at position 10 as hydrophobic amino acid at $\mathrm{pH} 2$. The dotted lines are non-sequential $\mathrm{H}-\mathrm{H}$ contact, which is considered as a unit of negative energy-1, and the sum of dotted lines is the minimal energy-12. 


\section{Original $\delta$-hemolysin}

Amino acid sequence
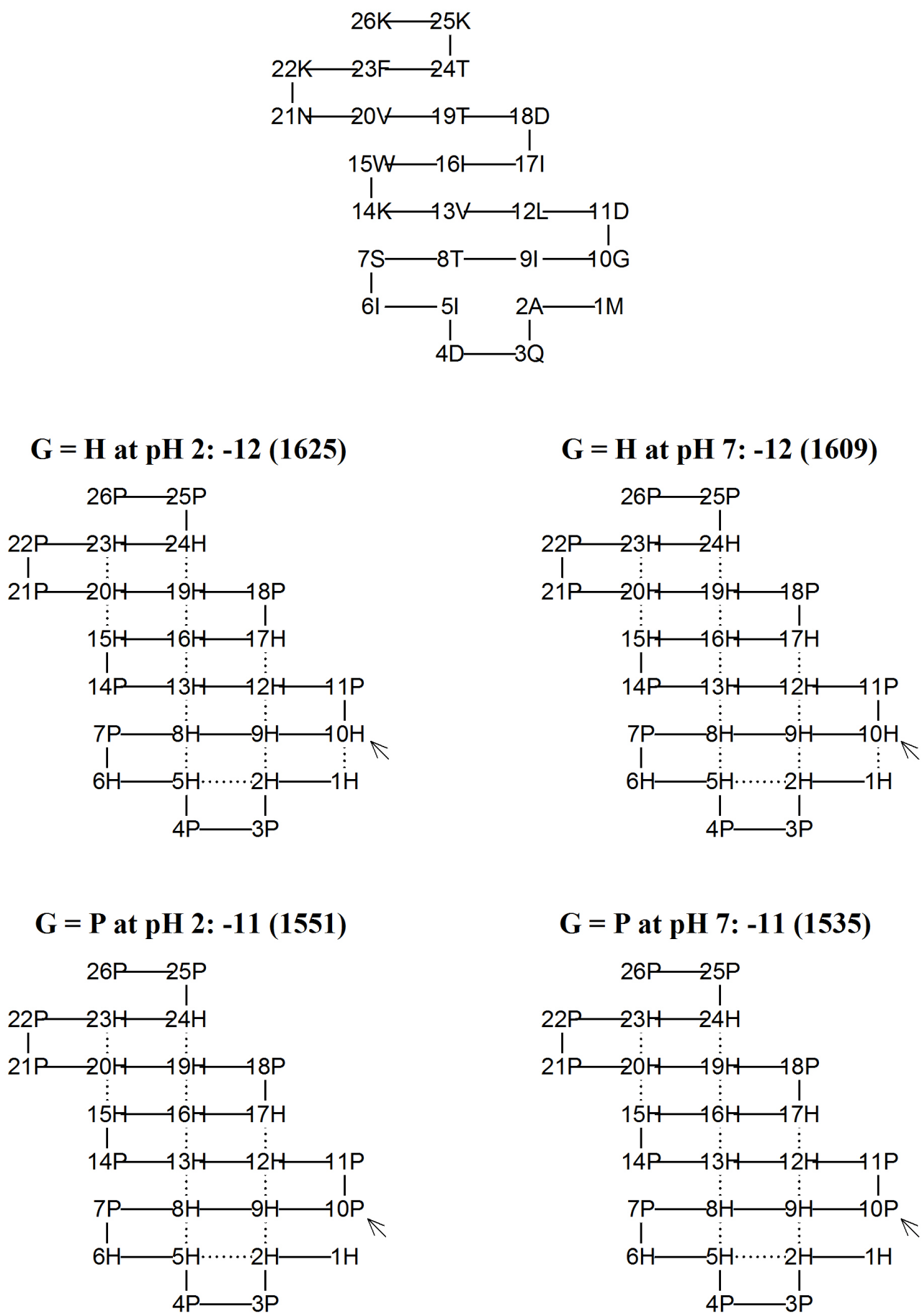

Figure 2. Amino acid sequence and HP folding structures of $\delta$-hemolysin in different classification of glycine as hydrophobic amino acid or as polar amino acid at $\mathrm{pH} 2$ or at $\mathrm{pH} 7$ with their native states of minimal energy. The dotted lines are non-sequential $\mathrm{H}-\mathrm{H}$ contact, and arrows indicate the difference with respect to whether glycine is considered as hydrophobic amino acid or as polar amino acid. 


\section{$\delta$-Hemolysin variant $\mathrm{Q} \rightarrow \mathrm{A}$ at position 3}

Amino acid sequence

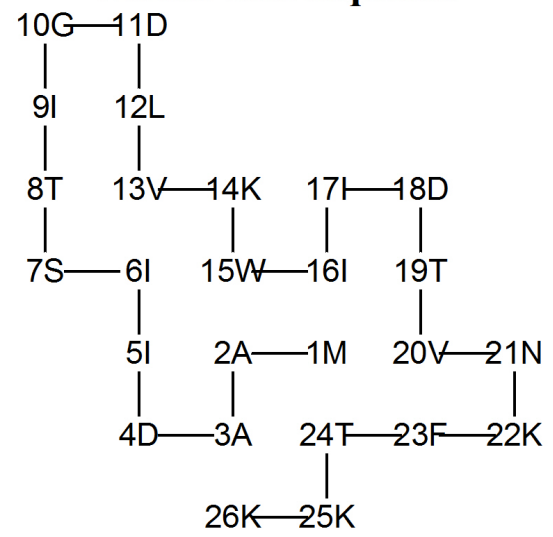

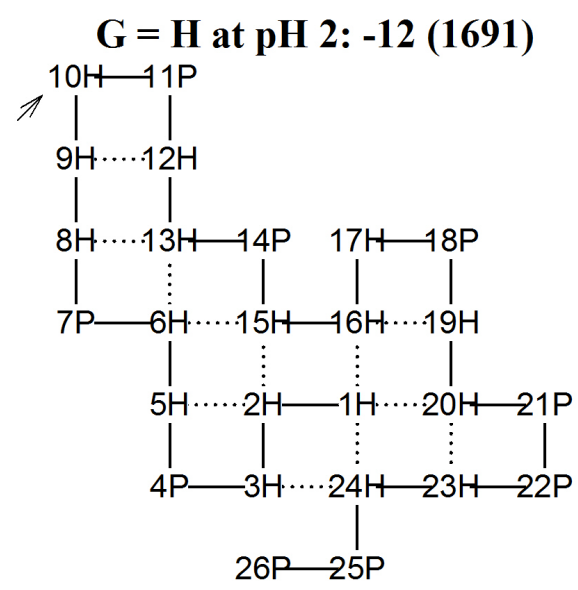

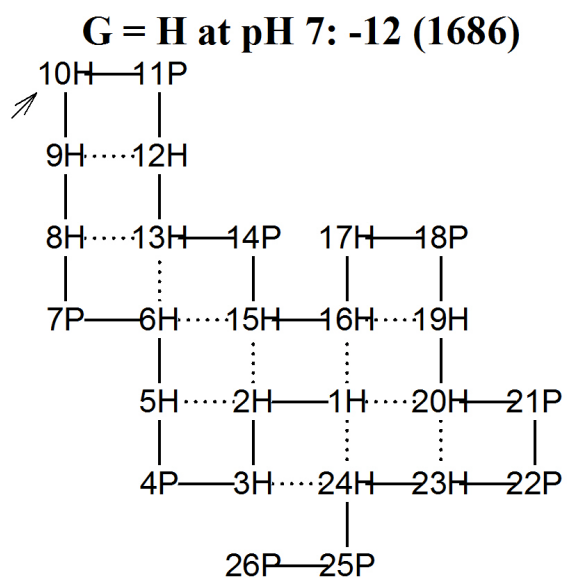
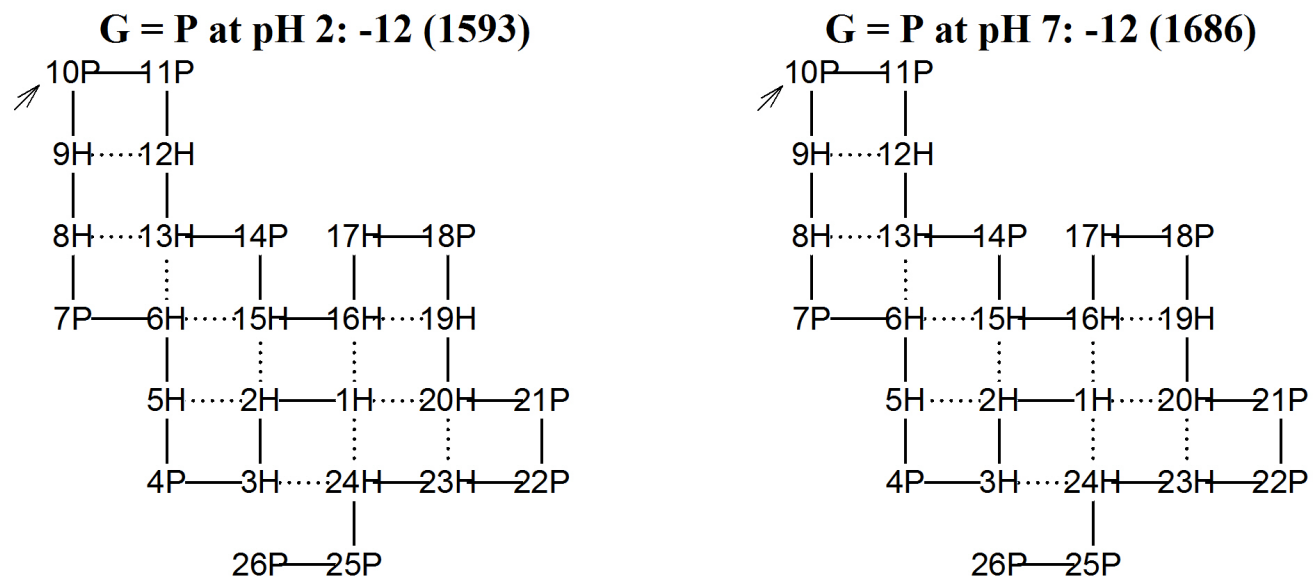

Figure 3. Amino acid sequences and $\mathrm{HP}$ folding structures of the variant $\mathrm{Q} \rightarrow \mathrm{A}$ at position 3 in different classification of glycine as hydrophobic amino acid or as polar amino acid at $\mathrm{pH} 2$ or at $\mathrm{pH} 7$ with their native states of minimal energy. The dotted lines are non-sequential $\mathrm{H}-\mathrm{H}$ contact, and arrows indicate the difference with respect to whether glycine is considered as hydrophobic amino acid or as polar amino acid. 


\section{$\delta$-Hemolysin variant GDL $\rightarrow$ VEF at positions 10-12}

\section{Amino acid sequence}

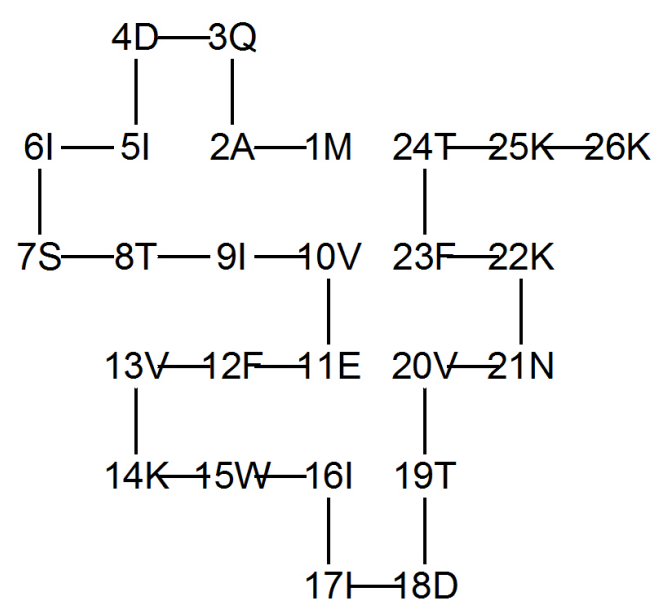

at pH 2: -13 (1757)

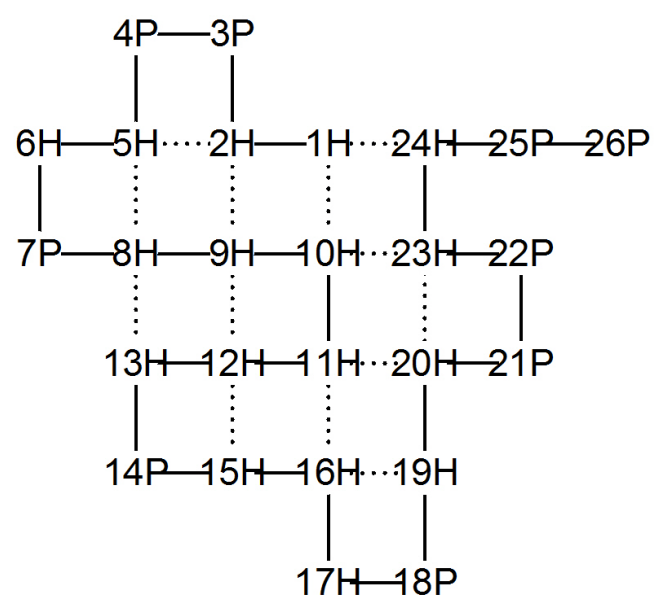

Amino acid sequence

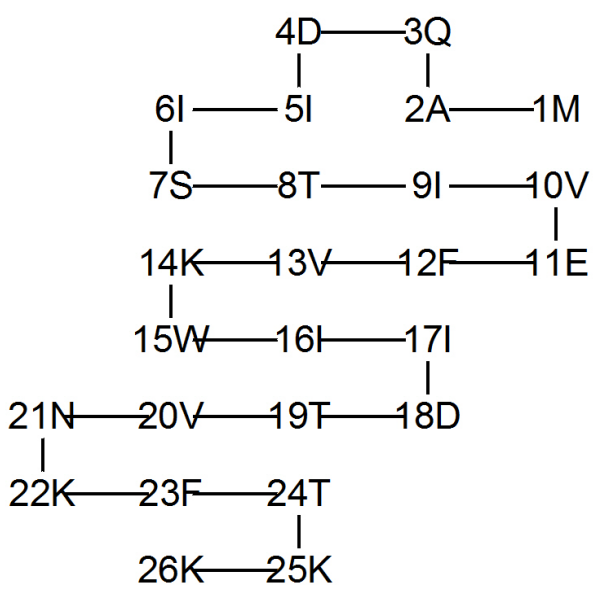

at $\mathrm{pH}$ 7: $-12(1691)$

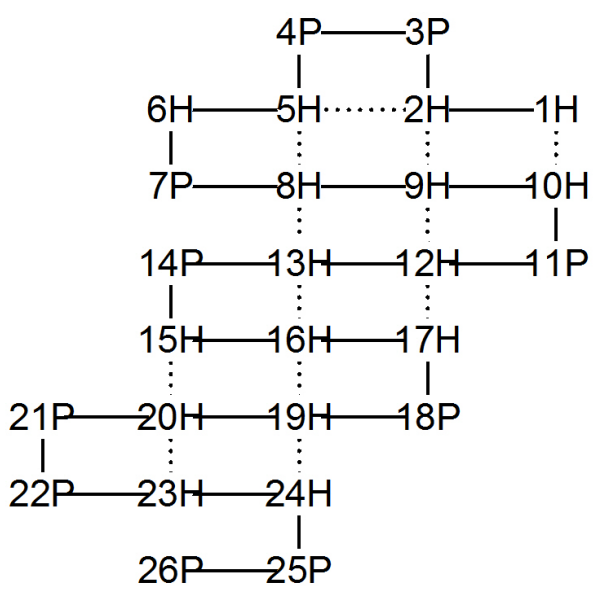

Figure 4. Amino acid sequences and HP folding structures of the variant GDL $\rightarrow$ VEF at positions 10 12 in different classification of at $\mathrm{pH} 2$ or at $\mathrm{pH} 7$ with their native states of minimal energy. The dotted lines are non-sequential $\mathrm{H}-\mathrm{H}$ contact, and arrows indicate the difference with respect to whether glycine is considered as hydrophobic amino acid or as polar amino acid.

are so many structures at a native state, it suggested that $\delta$-hemolysin might have sufficient structures to deal with various situations. Still, Table 3 indicated that assigning hydrophobicity index to each amino acid can help to distinguish folding structures at the same native state.

To our knowledge, the hydrophobic-hydrophilic-neutral (BPN) model is a comparable 2-dimensional model, which determines the optimal pathway for folding to native structure by means of enumerating all the possible folding pathways [30]. Yet, the energy landscape model deals with a funnel-like landscape biased toward the native structure [31,32]. Finally, the folding intermediate model is related to the stability and activation energy barriers between folding intermediates [33]. However, the detailed comparison among four models is beyond the scope of this article, and we hope to address this issue in near future. 


\section{$\delta$-Hemolysin variant $\mathrm{W} \rightarrow \mathrm{L}$ at position 15}

\section{Amino acid sequence}

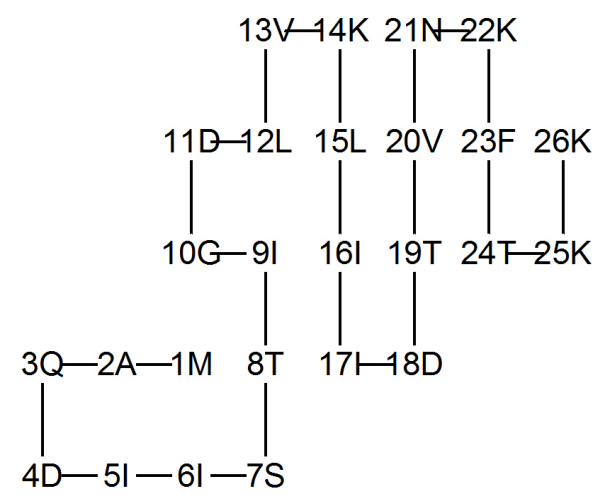

$\mathrm{G}=\mathrm{H}$ at pH 2: $-12(1684)$

$\mathrm{G}=\mathrm{H}$ at pH 7: -12 (1661)
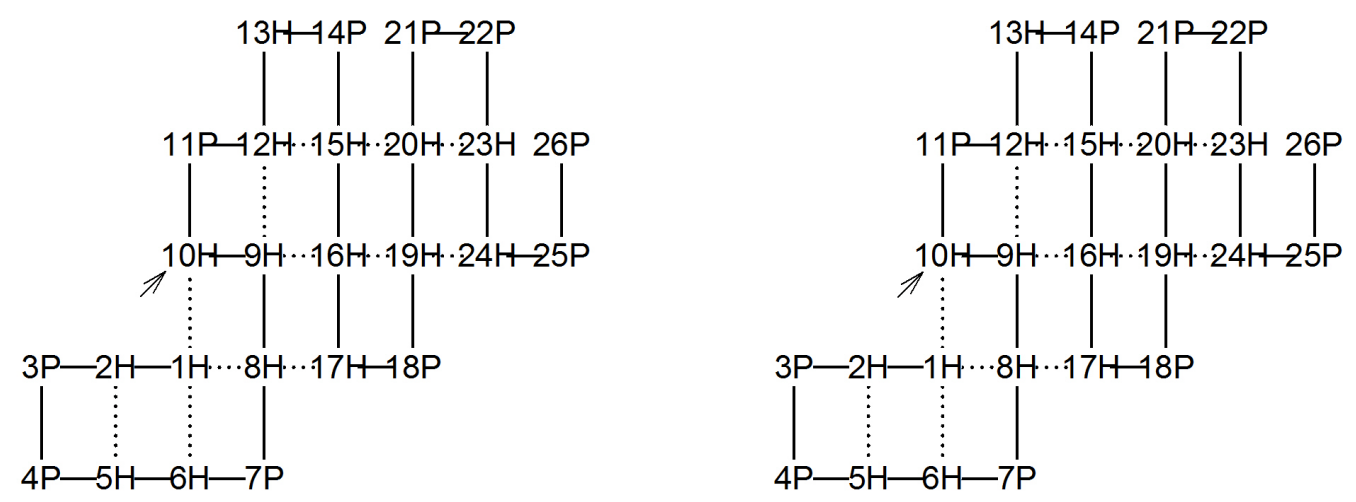

G= P at pH 2: -11 (1610)

G= P at pH 7: -11 (1587)
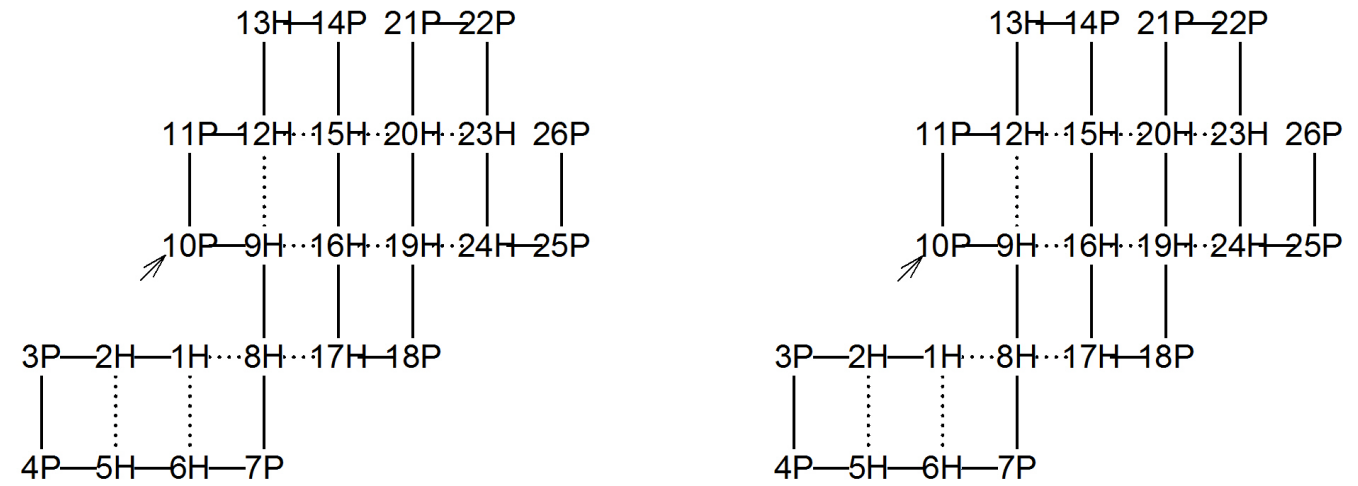

Figure 5. Amino acid sequences and HP folding structures of the variant $W \rightarrow L$ at position 15 in different classification of glycine as hydrophobic amino acid or as polar amino acid at $\mathrm{pH} 2$ or at $\mathrm{pH} 7$ with their native states of minimal energy. The dotted lines are non-sequential $\mathrm{H}-\mathrm{H}$ contact, and arrows indicate the difference with respect to whether glycine is considered as hydrophobic amino acid or as polar amino acid. 


\section{$\delta$-Hemolysin variant $\mathrm{ID} \rightarrow \mathrm{AE}$ at positions 17-18}

\section{Amino acid sequence}

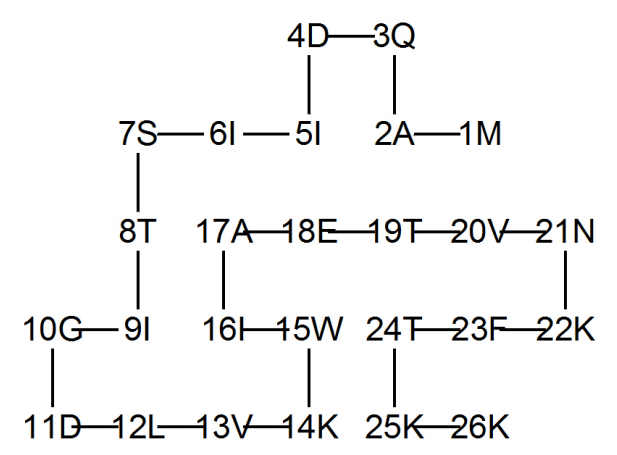

$\mathrm{G}=\mathrm{H}$ at pH 2: $-13(1640)$

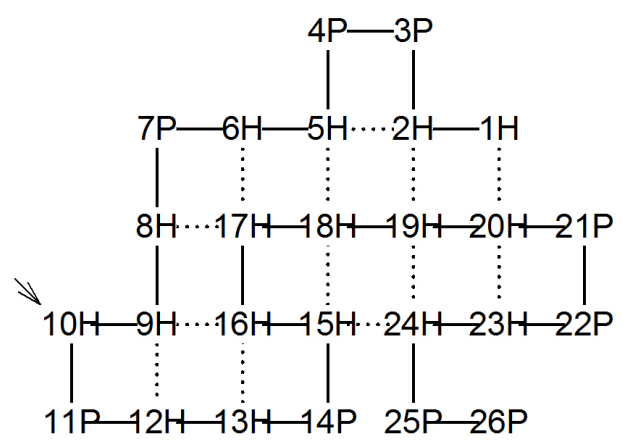

$G=P$ at pH 2: $-13(1640)$

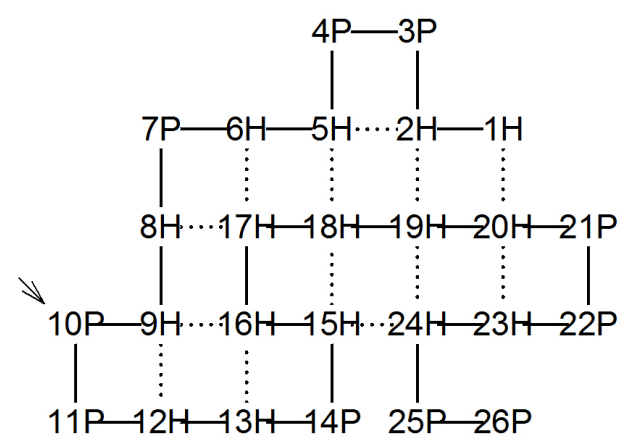

Amino acid sequence

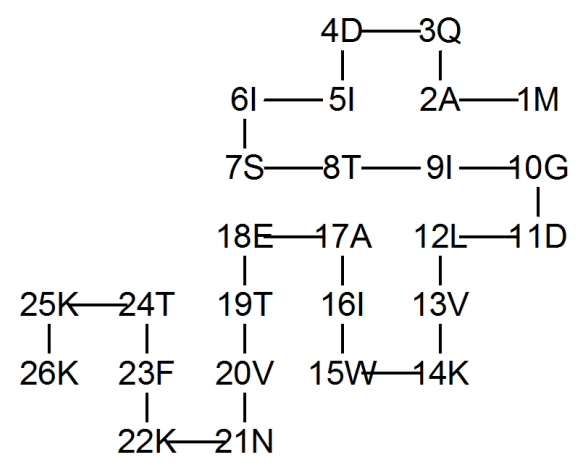

$\mathrm{G}=\mathrm{H}$ at pH 7: $-12(1516)$

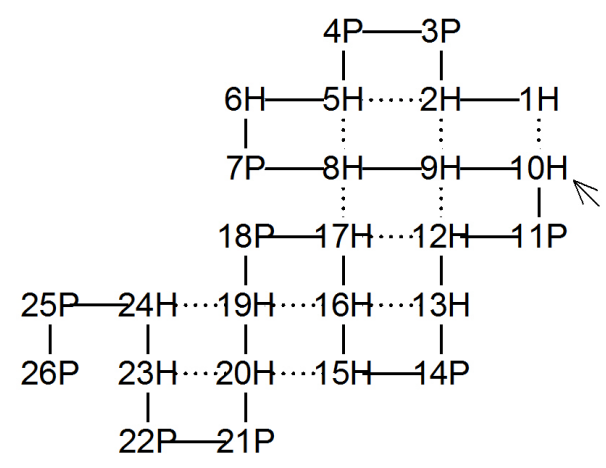

$G=P$ at pH 7: -11 (1419)

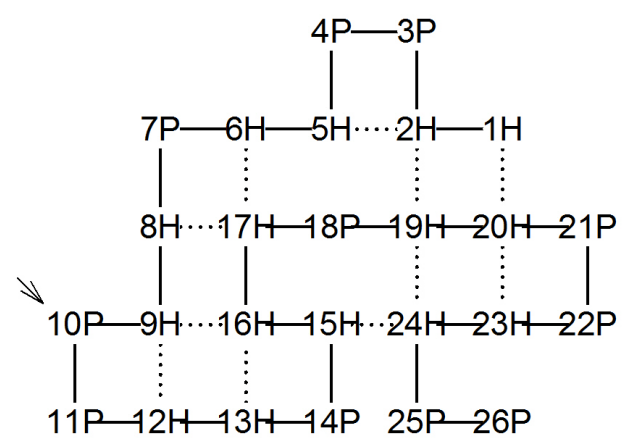

Figure 6. Amino acid sequences and HP folding structures of the variant ID $\rightarrow$ AE at positions 17 - 18 in different classification of glycine as hydrophobic amino acid or as polar amino acid at $\mathrm{pH} 2$ or at $\mathrm{pH} 7$ with their native states of minimal energy. The dotted lines are non-sequential $\mathrm{H}-\mathrm{H}$ contact, and arrows indicate the difference with respect to whether glycine is considered as hydrophobic amino acid or as polar amino acid. 


\section{$\delta$-Hemolysin variant $\mathrm{N} \rightarrow \mathrm{E}$ at position 21}

Amino acid sequence

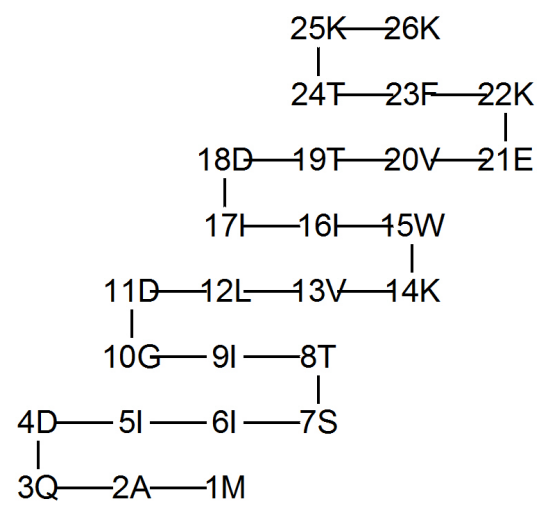

$G=H$ at pH 2: -12 (1765)

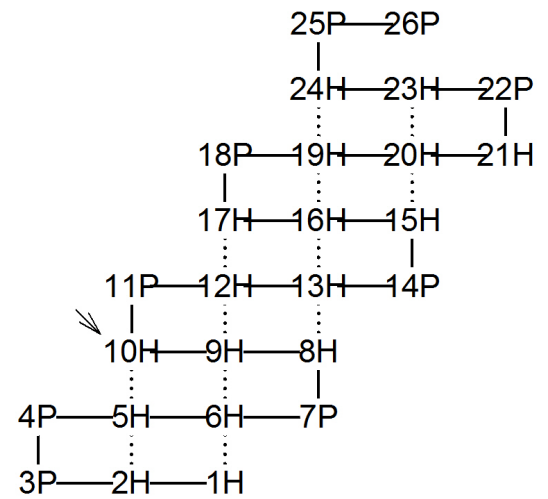

$G=P$ at pH 2: $-12(1628)$

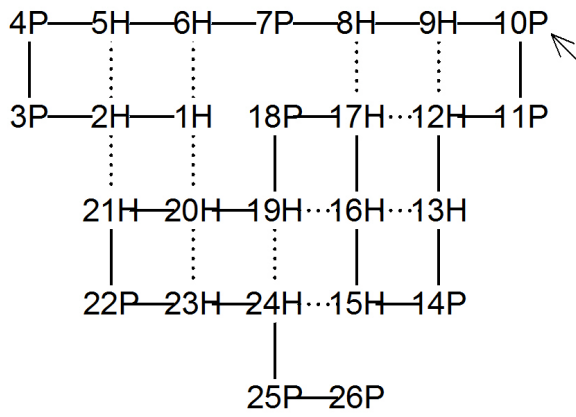

Amino acid sequence



$\mathbf{G}=\mathbf{H}$ at pH 7: -12 (1753)

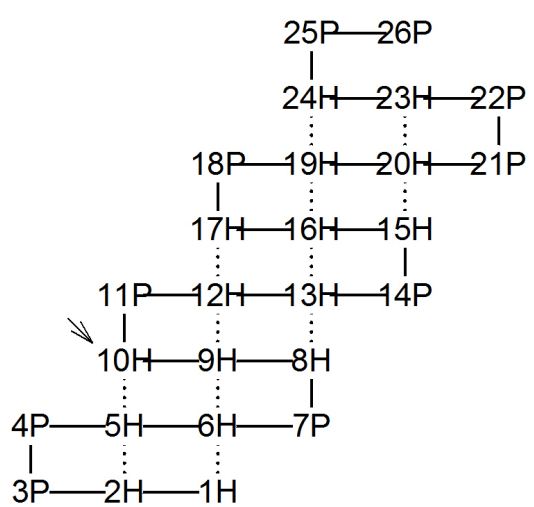

$G=P$ at pH 7: -11 (1654)

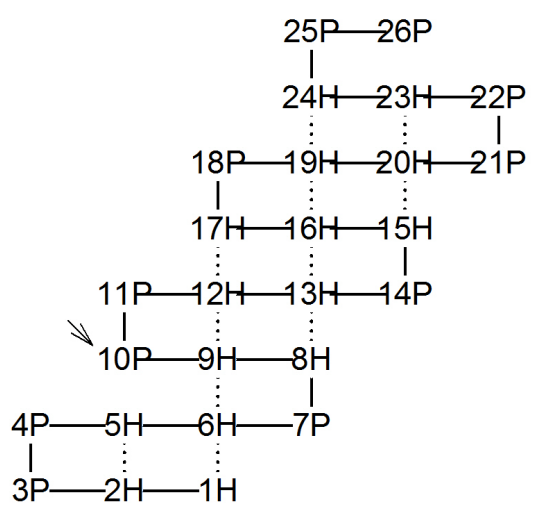

Figure 7. Amino acid sequence and $\mathrm{HP}$ folding structures of the variant $\mathrm{N} \rightarrow \mathrm{E}$ at position 21 in different classification of glycine as hydrophobic amino acid or as polar amino acid at $\mathrm{pH} 2$ or at $\mathrm{pH} 7$ with their native states of minimal energy. The dotted lines are non-sequential $\mathrm{H}-\mathrm{H}$ contact, and arrows indicate the difference with respect to whether glycine is considered as hydrophobic amino acid or as polar amino acid. 


\section{$\delta$-Hemolysin variant $T \rightarrow I$ at position 24}

Amino acid sequence

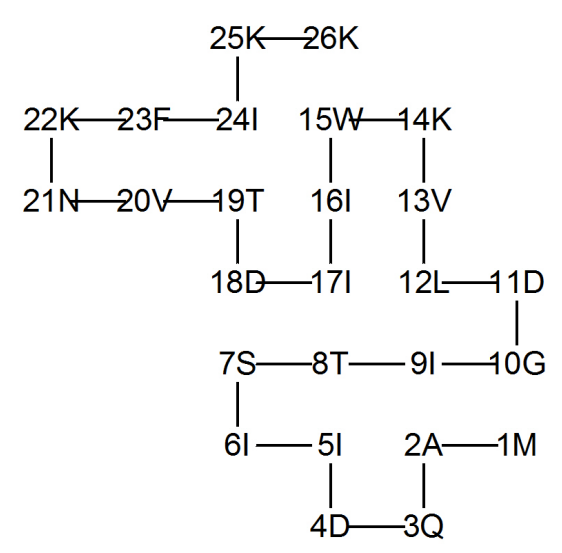

$$
G=H \text { at pH 2: }-12(1754)
$$

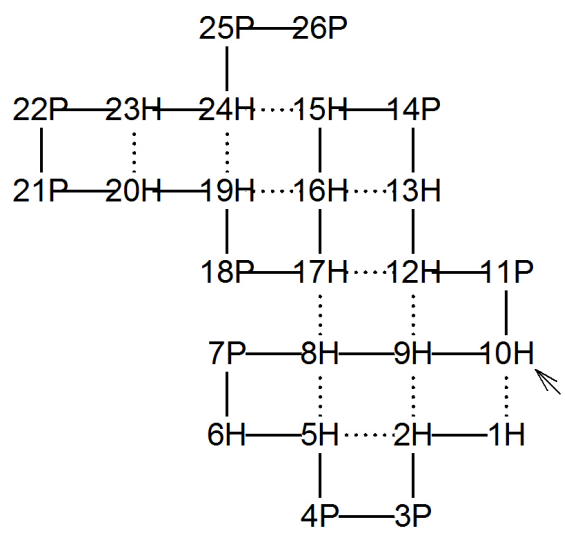

$$
\mathrm{G}=\mathrm{P} \text { at } \mathrm{pH} 2:-11(1680)
$$

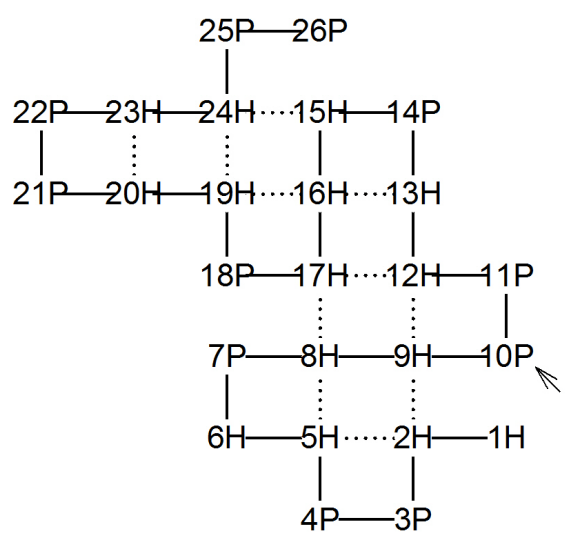

$$
\mathrm{G}=\mathrm{H} \text { at pH 7: }-12(1741)
$$

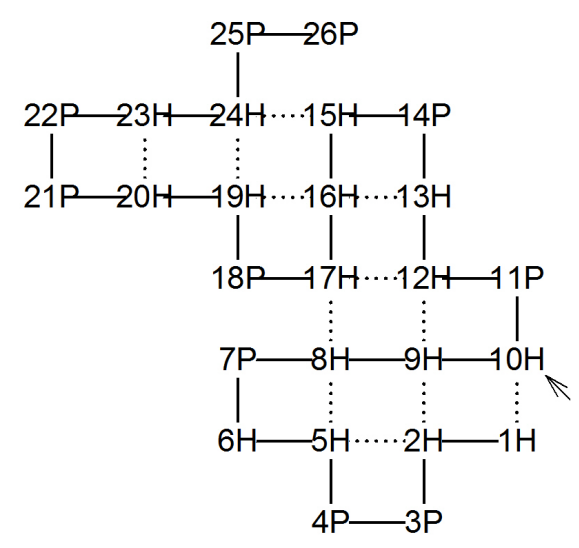

$$
\text { G = P at pH 7: -11 (1667) }
$$

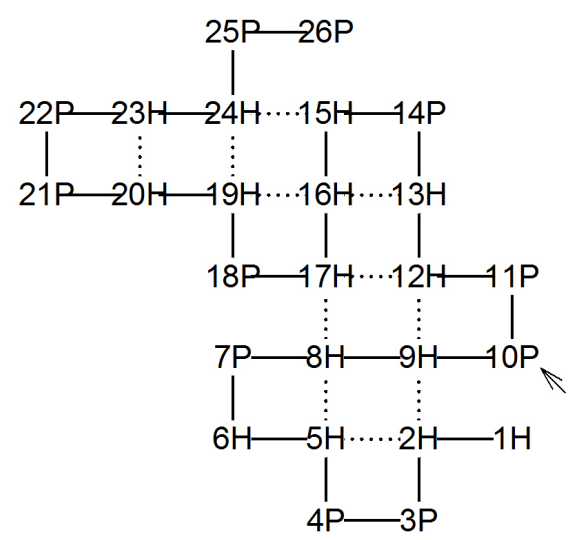

Figure 8. Amino acid sequence and HP folding structures of the variant $\mathrm{T} \rightarrow \mathrm{I}$ at position 24 in different classification of glycine as hydrophobic amino acid or as polar amino acid at $\mathrm{pH} 2$ or at $\mathrm{pH} 7$ with their native states of minimal energy. The dotted lines are non-sequential $\mathrm{H}-\mathrm{H}$ contact, and arrows indicate the difference with respect to whether glycine is considered as hydrophobic amino acid or as polar amino acid. 
Table 3. Characteristics of native state of $\delta$-hemolysin and its variants. Negative value is the minimal energy, the number of folding structures at given native state is in parentheses, the number of native states defined according to the hydrophobicity index is in brackets, the range of sums of hydrophobicity index is in braces.

\begin{tabular}{|c|c|c|c|c|}
\hline \multirow{3}{*}{$\begin{array}{c}\delta \text {-hemolysin and } \\
\text { its variants }\end{array}$} & \multicolumn{4}{|c|}{ Characteristics of native state } \\
\hline & \multicolumn{2}{|c|}{$\mathrm{pH} 2$} & \multicolumn{2}{|c|}{$\mathrm{pH} 7$} \\
\hline & $\mathrm{G}=\mathrm{H}$ & $\mathrm{G}=\mathrm{P}$ & $\mathrm{G}=\mathrm{H}$ & $\mathrm{G}=\mathrm{P}$ \\
\hline \multirow{2}{*}{$\delta$-hemolysin } & $-12(2160)$ & $-11(7552)$ & $-12(2160)$ & $-11(7552)$ \\
\hline & {$[51]\{1507-1931\}$} & [106] $\{1433-1839\}$ & {$[58]\{1496-1926\}$} & {$[120]\{1422-1830\}$} \\
\hline \multirow{2}{*}{$\begin{array}{l}\text { Variant position 3, } \\
\qquad \mathrm{Q} \rightarrow \mathrm{A}\end{array}$} & $-12(6328)$ & $-12(760)$ & $-12(6328)$ & $-12(760)$ \\
\hline & {$[131]\{1306-1931\}$} & [7] $\{1517-1641\}$ & {$[164]\{1306-1962\}$} & {$[23]\{1483-1859\}$} \\
\hline Variant positions & $-13(744)$ & $-13(744)$ & $-12(2160)$ & $-12(2160)$ \\
\hline $10-12, \mathrm{GDL} \rightarrow \mathrm{VEF}$ & [23] $\{1586-1949\}$ & {$[23]\{1586-1949\}$} & {$[55]\{1578-2008\}$} & {$[55]\{1578-2008\}$} \\
\hline \multirow{2}{*}{$\begin{array}{l}\text { Variant position 15, } \\
\qquad \mathrm{W} \rightarrow \mathrm{L}\end{array}$} & $-12(2160)$ & $-11(7552)$ & $-12(2160)$ & $-11(7552)$ \\
\hline & {$[53]\{1523-1947\}$} & {$[94]\{1449-1866\}$} & {$[58]\{1496-1926\}$} & {$[120]\{1422-1830\}$} \\
\hline Variant positions & $-13(696)$ & $-13(264)$ & $-12(2160)$ & $-11(7552)$ \\
\hline $17-18, \mathrm{ID} \rightarrow \mathrm{AE}$ & {$[17]\{1467-1770\}$} & [6] $\{1575-1770\}$ & {$[57]\{1403-1810\}$} & {$[136]\{1329-1721\}$} \\
\hline \multirow{2}{*}{$\begin{array}{l}\text { Variant position 21, } \\
\qquad N \rightarrow E\end{array}$} & $-12(7312)$ & $-12(432)$ & $-12(2160)$ & $-11(7552)$ \\
\hline & {$[150]\{1310-1931\}$} & {$[16]\{1426-1855\}$} & {$[58]\{1496-1926\}$} & {$[120]\{1422-1830\}$} \\
\hline \multirow{2}{*}{$\begin{array}{l}\text { Variant position 24, } \\
\qquad \mathrm{T} \rightarrow \mathrm{I}\end{array}$} & $-12(2160)$ & $-11(7552)$ & $-12(2160)$ & $-11(7552)$ \\
\hline & {$[45]\{1660-2018\}$} & [105] $\{1586-1989\}$ & {$[52]\{1645-2012\}$} & {$[116]\{1571-1997\}$} \\
\hline
\end{tabular}

\section{CONCLUSION}

In conclusion, this study takes a step forward from our previous studies [34-36] in following points: 1) a protein can find any of its folding structure in one eighth folding structures because of symmetry, which reduces the time required for folding, 2) the impact of $\mathrm{pH}$ on folding structures is various and associated directly with the amino acid sequence itself, 3) the change of folding structures in variants appeared different case by case, and 4) assigning hydrophobicity index to each amino acid is a way to distinguish folding structures at the same native state.

\section{FUND}

This study was supported by National Natural Science Foundation of China (31460296 and 31560315), and Key Project of Guangxi Scientific Research and Technology Development Plan (AB17190534).

\section{CONFLICTS OF INTEREST}

The authors declare no conflicts of interest regarding the publication of this paper. 


\section{REFERENCES}

1. Burley, S.K., Berman, H.M., Kleywegt, G.J., Markley, J.L., Nakamura, H. and Velankar, S. (2017) Protein Data Bank (PDB): The Single Global Macromolecular Structure Archive. In: Wlodawer, A., Dauter, Z. and Jaskolski, M., Eds., Protein Crystallography: Methods and Protocols, Methods in Molecular Biology, Vol. 1607, Springer, Berlin, 627-641. https://doi.org/10.1007/978-1-4939-7000-1_26

2. Rose, P.W., Prlić, A., Altunkaya, A., Bi, C., Bradley, A.R., Christie, C.H., Costanzo, L.D., Duarte, J.M., Dutta, S., Feng, Z., Green, R.K., Goodsell, D.S., Hudson, B., Kalro, T., Lowe, R., Peisach, E., Randle, C., Rose, A.S., Shao, C., Tao, Y.P., Valasatava, Y., Voigt, M., Westbrook, J.D., Woo, J., Yang, H., Young, J.Y., Zardecki, C., Berman, H.M. and Burley, S.K. (2017) The RCSB Protein Data Bank: Integrative View of Protein, Gene and 3D Structural Information. Nucleic Acids Research, 45, D271-D281. https://doi.org/10.1093/nar/gkw1000

3. Dill, K.A. (1985) Theory for the Folding and Stability of Globular Proteins. Biochemistry, 24, 1501-1509. https://doi.org/10.1021/bi00327a032

4. Lau, K.F. and Dill, K.A. (1989) A Lattice Statistical Mechanics Model of the Conformation and Sequence Spaces of Proteins. Macromolecules, 22, 3986-3997. https://doi.org/10.1021/ma00200a030

5. Unger, R. and Moult, J. (1993) Finding the Lowest Free Energy Conformation of a Protein is a NP-Hard Problem: Proof and Implications. Bulletin of Mathematical Biology, 55, 1183-1198.

https://doi.org/10.1016/S0092-8240(05)80169-7

6. Berger, B. and Leight, T. (1998) Protein Folding in the Hydrophobic-Hydrophilic (HP) Model Is NP-Complete. Journal of Computational Biology, 5, 27-40. https://doi.org/10.1089/cmb.1998.5.27

7. http://www.claymath.org/millennium-problems/millennium-prize-problems

8. Blicharz, L., Rudnicka, L. and Samochocki, Z. (2019) Staphylococcus aureus: An Underestimated Factor in the Pathogenesis of Atopic Dermatitis? Postepy Dermatologii i Alergologii (Advances in Dermatology and Allergology), 36, 11-17. https://doi.org/10.5114/ada.2019.82821

9. Liu, Y. and Zhang, Z.Y. (2016) Effects of Staphylococcus aureus Hemolysin on Nasal Mucociliary Clearance System. Journal of Clinical Otorhinolaryngology, Head, and Neck Surgery, 30, 1415-1418.

10. Yamashita, K., Kawai, Y., Tanaka, Y., Hirano, N., Kaneko, J., Tomita, N., Ohta, M., Kamio, Y., Yao, M. and Tanaka, I. (2011) Crystal Structure of the Octameric Pore of Staphylococcal $\gamma$-Hemolysin Reveals the $\beta$-Barrel Pore Formation Mechanism by Two Components. Proceedings of the National Academy of Sciences of the United States of America, 108, 17314-17319. https://doi.org/10.1073/pnas.1110402108

11. Gouaux, E. (1998) alpha-Hemolysin from Staphylococcus aureus: An Archetype of Beta-Barrel, Channel-Forming Toxins. Journal of Structural Biology, 121, 110-122. https://doi.org/10.1006/jsbi.1998.3959

12. Dalla Serra, M., Coraiola, M., Viero, G., Comai, M., Potrich, C., Ferreras, M., Baba-Moussa, L., Colin, D.A., Menestrina, G., Bhakdi, S. and Prévost, G. (2005) Staphylococcus aureus Bicomponent Gamma-Hemolysins, $\mathrm{Hlg} \mathrm{A}, \mathrm{HlgB}$, and $\mathrm{HlgC}$, Can Form Mixed Pores Containing All Components. Journal of Chemical Information and Modeling, 45, 1539-1545. https://doi.org/10.1021/ci050175y

13. Verdon, J., Girardin, N., Lacombe, C., Berjeaud, J.M. and Héchard, Y. (2009) Delta-Hemolysin, an Update on a Membrane-Interacting Peptide. Peptides, 30, 817-823. https://doi.org/10.1016/j.peptides.2008.12.017

14. Verdon, J., Berjeaud, J.M., Lacombe, C. and Héchard, Y. (2008) Characterization of Anti-Legionella Activity of Warnericin RK and Delta-Lysin I from Staphylococcus warneri. Peptides, 29, 978-984.

https://doi.org/10.1016/j.peptides.2008.01.017

15. Moise, P.A., Forrest, A., Bayer, A.S., Xiong, Y.Q., Yeaman, M.R. and Sakoulas, G. (2010) Factors Influencing Time to Vancomycin-Induced Clearance of Nonendocarditis Methicillin-Resistant Staphylococcus aureus Bacteremia: Role of Platelet Microbicidal Protein Killing and Agr Genotypes. Journal of Infectious Diseases, 201, 
233-240. https://doi.org/10.1086/649429

16. Quave, C.L., Plano, L.R. and Bennett, B.C. (2011) Quorum Sensing Inhibitors of Staphylococcus aureus from Italian Medicinal Plants. Planta Medica, 77, 188-195. https://doi.org/10.1055/s-0030-1250145

17. Verdon, J., Labanowski, J., Sahr, T., Ferreira, T., Lacombe, C., Buchrieser, C., Berjeaud, J.M. and Héchard, Y. (2011) Fatty Acid Composition Modulates Sensitivity of Legionella pneumophila to Warnericin RK, an Antimicrobial Peptide. Biochimica et Biophysica Acta, 1808, 1146-1153. https://doi.org/10.1016/j.bbamem.2010.12.011

18. Unger, R. and Moult, J. (1993) Genetic Algorithm for Protein Folding Simulations. Journal of Molecular Biology, 231, 75-81. https://doi.org/10.1006/jmbi.1993.1258

19. Ramakrishnan, R., Ramachandran, B. and Pekny, J.F. (1997) A Dynamic Monte Carlo Algorithm for Exploration of Dense Conformational Spaces in Heteropolymers. Journal of Chemical Physics, 106, 2425-2818. https://doi.org/10.1063/1.473791

20. Shmygelska, A. and Hoons, H.H. (2005) An Ant Colony Optimisation Algorithm for the 2D and 3D Hydrophobic Polar Protein Folding Problem. BMC Bioinformatics, 6, 30-51.

21. Bastolla, U., Frauenkron, H., Gerstner, E., Grassberger, P. and Nadler, W. (1998) Testing a New Monte Carlo Algorithm for Protein Folding. Proteins: Structure, Function, and Genetics, 32, 52-66. https://doi.org/10.1002/(SICI)1097-0134(19980701)32:1<52::AID-PROT7>3.0.CO;2-G

22. Beutler, T.C. and Dill, K.A. (1996) A Fast Conformational Search Strategy for Finding Low Energy Structures of Model Proteins. Protein Science, 5, 2037-2043. https://doi.org/10.1002/pro.5560051010

23. Zhao, X.C. (2008) Advances on Protein Folding Simulations Based on the Lattice HP Models with Natural Computing. Applied Soft Computing, 8, 1029-1040. https://doi.org/10.1016/j.asoc.2007.03.012

24. UniProt Consortium T. (2018) UniProt: The Universal Protein Knowledgebase. Nucleic Acids Research, 46, 2699. https://doi.org/10.1093/nar/gky092

25. https://www.uniprot.org/uniprot/P0C1V1

26. https://www.sigmaaldrich.com/china-mainland/zh/life-science/metabolomics/learning-center/amino-acid-refer ence-chart.html

27. Levinthal, C. (1968) Are There Pathways far Protein Folding? Journal of Chemistry, Physics, and Physical Biology, 65, 44. https://doi.org/10.1051/jcp/1968650044

28. van der Kamp, M.W. and Daggett, V. (2010) Influence of $\mathrm{pH}$ on the Human Prion Protein: Insights into the Early Steps of Misfolding. Biophysical Journal, 99, 2289-2298. https://doi.org/10.1016/j.bpj.2010.07.063

29. Borkar, A.N., Rout, M.K. and Hosur, R.V. (2011) Visualization of Early Events in Acetic Acid Denaturation of HIV-1 Protease: A Molecular Dynamics Study. PLoS ONE, 6, e19830. https://doi.org/10.1371/journal.pone.0019830

30. Nymeyer, H., García, A.E. and Onuchic, J.N. (1998) Folding Funnels and Frustration in Off-Lattice Minimalist Protein Landscapes. Proceedings of the National Academy of Sciences of the United States of America, 95, 5921-5828. https://doi.org/10.1073/pnas.95.11.5921

31. Leopold, P.E., Montal, M. and Onuchic, J.N. (1992) Protein Folding Funnels: A Kinetic Approach to the Sequence-Structure Relationship. Proceedings of the National Academy of Sciences of the United States of America, 89, 8721-8725. https://doi.org/10.1073/pnas.89.18.8721

32. Onuchic, J.N., Luthey-Schulten, Z. and Wolynes, P.G. (1997) Theory of Protein Folding: The Energy Landscape Perspective. Annual Review of Physical Chemistry, 48, 545-600. https://doi.org/10.1146/annurev.physchem.48.1.545

33. Laurents, D.V. and Baldwin, R.L. (1998) Protein Folding: Matching Theory and Experiment. Biophysical Journal, 75, 428-434. https://doi.org/10.1016/S0006-3495(98)77530-7 
34. Yan, S. and Wu, G. (2012) Analysis on Folding of Misgurin Using 2-Dimensional HP Model. Proteins: Structure, Function, and Bioinformatics, 80, 764-773. https://doi.org/10.1002/prot.23233

35. Yan, S. and Wu, G. (2012) Detailed Folding Structures of Kappa-Conotoxin RIIIJ and Its Mutageneses Obtained from 2-Dimensional HP Model. Protein \& Peptide Letters, 19, 567-572. https://doi.org/10.2174/092986612800190982

36. Yan, S. and $\mathrm{Wu}, \mathrm{G}$. (2012) Detailed Folding Structures of M-Lycotoxin-Hcla and Its Mutageneses Using 2-Dimensional HP Model. Molecular Simulation, 38, 809-822. https://doi.org/10.1080/08927022.2012.654473 